\title{
STATE WAGE-PAYMENT LAWS, THE PENSION PROTECTION ACT OF 2006, AND 401(k) SAVING BEHAVIOR
}

\author{
Gary V. Engelhardt \\ CRR WP 2010-14 \\ Date Released: November 2010 \\ Date Submitted: October 2010 \\ Center for Retirement Research at Boston College \\ Hovey House \\ 140 Commonwealth Avenue \\ Chestnut Hill, MA 02467 \\ Tel: 617-552-1762 Fax: 617-552-0191 \\ http://crr.bc.edu
}

Gary Engelhardt is a professor of economics at Syracuse University. The research reported herein was performed pursuant to a grant from the U.S. Social Security Administration (SSA) funded as part of the Retirement Research Consortium (RRC). The opinions and conclusion expressed are solely those of the author and do not represent the opinions or policy of SSA, any agency of the federal government, the RRC, Syracuse University, or Boston College.

(C) 2010, by Gary V. Engelhardt. All rights reserved. Short sections of text, not to exceed two paragraphs, may be quoted without explicit permission provided that full credit, including $\left({ }^{C}\right.$ notice, is given to the source. 


\begin{abstract}
About the Center for Retirement Research
The Center for Retirement Research at Boston College, part of a consortium that includes parallel centers at the University of Michigan and the National Bureau of Economic Research, was established in 1998 through a grant from the Social Security Administration. The Center's mission is to produce first-class research and forge a strong link between the academic community and decision makers in the public and private sectors around an issue of critical importance to the nation's future. To achieve this mission, the Center sponsors a wide variety of research projects, transmits new findings to a broad audience, trains new scholars, and broadens access to valuable data sources.
\end{abstract}

\author{
Center for Retirement Research at Boston College \\ Hovey House \\ 140 Commonwealth Avenue \\ Chestnut Hill, MA 02467 \\ phone: 617-552-1762 fax: 617-552-0191 \\ e-mail: crr@bc.edu \\ crr.bc.edu
}

Affiliated Institutions:

The Brookings Institution

Massachusetts Institute of Technology

Syracuse University

Urban Institute 


\begin{abstract}
State wage-payment laws, which forbid deductions from wages and salaries without the written permission of the employee, constituted a binding constraint on firms' choices to adopt automatic enrollment in 401(k) plans prior to 2006. Since the passage of the Pension Protection Act of 2006, which clarified the legality of auto-enroll plans and superseded these state laws, 401(k) participation has been higher in states that previously required written permission.
\end{abstract}




\section{Introduction}

401(k) plans are the dominant form of employer-provided retirement saving in the United States. In the 1990s, some plans began to adopt automatic enrollment, whereby employees are defaulted into participating in and deferring salary through the plan, but may opt out. Despite research suggesting that automatic enrollment was highly effective in promoting employee retirement saving (e.g., Madrian and Shea, 2001), by 2005 less than 10 percent of plans had such a provision (U.S. Bureau of Labor Statistics, 2007).

Although the Internal Revenue Service (IRS) had issued rulings in 1998 and 2000 that automatic enrollment was permissible for newly hired and existing employees, respectively, an oft-cited reason in the industry and popular press for the reluctance of employers to adopt such plans was that this design ran counter to some states' wage-payment laws, which forbid wage deductions without the written permission of the employee, something not obtained explicitly in auto-designed plans. However, there has been no evidence that these concerns constituted a binding constraint on firms’ pension choices.

I present evidence that these laws indeed significantly deterred the expansion of 401(k) participation through automatic enrollment. I focus on the impact of the Pension Protection Act of 2006 (PPA2006), which set forth federal rules for the legality of auto-enrolled plans that superseded any state wage-payment laws (Purcell, 2006), on 401(k) saving behavior in a panel of 703 mid-career individuals working for non-federal employers and who self-reported being eligible to participate in a 401(k). ${ }^{1} \quad$ Specifically, I use a natural experiment methodology and compare the 401(k) participation and contributions of workers residing in states with wagepayment laws requiring written permission versus those in states without such laws before (2004) versus after (2008) passage of PPA2006.

\footnotetext{
${ }^{1}$ Federal employees are exempt from state wage-payment laws.
} 


\section{Descriptive Statistics and Estimation Framework}

Table 1 gives basic characteristics of the sample, which is drawn for calendar years 2004 and 2008 from the Early Baby Boomer (EBB) cohort of the Health and Retirement Study (HRS). The sample consists of individuals in their 40s and 50s, young enough so that automatic enrollment can have an impact on 401(k) accumulations, but old enough that retirement is not a distant prospect. They are primarily white, married, with a college education.

As shown in Table 2, there are 26 states that ban wage deductions without written permission of the employee. In eight states, state employees are exempt from these laws; in seven states, local public sector employees are exempt. The final two columns of the table show combined administrative, criminal, and civil penalties for violations of the law. They range widely. In some states, like Connecticut, Delaware, and Hawaii, the fines are levied on the firm on a per-employee basis for the violation and are very steep. In other states, while illegal, deductions do not carry explicit fines. Overall, there is substantial cross-state variation in how states treat and penalize wage deductions.

Unfortunately, the HRS does not have direct measures of whether those individuals included in 401(k) plans were automatically enrolled. However, a number of recent studies have documented a strong, direct link between the passage of PPA2006 and subsequent substantial growth in auto-enrolled plans, including Nessmith, Utkus, and Young (2007) and VanDerhei (2010), among others. The former is based on administrative plan data at Vanguard on 50 large plans adopting automatic enrollment; the latter is based on a very large set of plans maintained by ICI/EBRI. Therefore, because of these findings, I take a reduced-form approach. 
Let $i$ index the individual, $s$ the state of residence, and $t$ the calendar year, then I estimate the following econometric specification:

$$
C_{i s t}=\boldsymbol{\alpha} \mathbf{x}_{\text {ist }}+\boldsymbol{\beta} \boldsymbol{\kappa}_{\text {ist }}+\delta_{1} y_{\text {ist }}+\delta_{2} y_{i s t}^{2}+\gamma D_{\text {ist }}^{\text {Pension }}+\theta D_{i s}^{\text {Written }} \times D_{t}^{\text {After } 2006}+u_{\text {ist }} .
$$

The dependent variable, $C$, is $401(\mathrm{k})$-saving outcome, modeled as a function of $\mathbf{x}$, a set of controls for demographics (including a constant), $\mathbf{\kappa}$, employment characteristics, a quadratic in earnings, $y$, a dummy variable for other (non-401(k)) pension coverage on the job, $D^{\text {Pension }}$, and an interaction term. The first factor in this term, $D^{\text {Written }}$, is a dummy variable that takes on a value of one if the individual's employer is required by state law to obtain written permission before making salary deferrals, and zero otherwise. State of residence was determined using the HRS restricted-access geo-code files. The second factor, $D^{\text {After } 2006}$, is a dummy variable that takes on a value of one if the calendar year is after 2006 (post-PPA) and zero otherwise (prePPA).

The disturbance term, $u$, is modeled as

$$
u_{i s t}=v_{i}+\psi_{s}+\xi_{t}+\varepsilon_{i s t}
$$

in which $\psi$ is a vector of state dummies, $\xi$ is a calendar-year dummy that takes on a value of one after 2006 and zero otherwise, and $\varepsilon$ is white noise. The term $v$ in (2) is an individualspecific $401(\mathrm{k})$ saving effect that is treated as a normally distributed random variable. The primary objective is to obtain consistent estimates of $\theta$, which measures the differential impact of working for an employer subject to wage-payment laws requiring written permission, before versus after the adoption of PPA2006, holding earnings, other pension coverage, and other factors constant. Hence, estimates of $\theta$ are akin to difference-in-difference estimates of the impact of the Act and, once the state and calendar-year effects are included in (2), are identified primarily by state-by-calendar-year variation in the opportunity to adopt auto-enrollment 401(k) 
plans promoted by the passage of the PPA2006. In addition, there is some within-state-by-year variation in the interaction term, because some states requiring permission exempted certain classes of workers (see Table 2).

\section{Empirical Findings}

Column 1 of Table 3 shows the baseline random-effects probit parameter estimates, omitting the demographic and employment characteristics, with marginal effects in brackets. Controlling for state, year, other pension coverage, and earnings, on average, 401(k) participation was 9.7 percentage points higher for workers in states requiring written permission (relative to those in states that did not) after (relative to before) the law change. This estimated impact is robust to the inclusion of the demographic factors (dummies for age, white, female, married, widowed/divorced, some college, and college graduate - in column 2), but falls to just under 7 percentage points with the inclusion of the employment characteristics (union, firm size, industry, occupation, and job tenure).

If these estimates are truly picking up the impact of the state laws as constraints on firm pension choice, then participation after PPA2006 should be differentially higher in states with stiffer penalties for wage-payment violations. I find evidence of this in the final column, in which the penalty figures in columns 3 and 4 of Table 2 are expressed on a per-employee basis

and (triple-) interacted with $D_{i s}^{\text {Written }} \times D_{t}^{\text {After } 2006}$. Participation is 4.2 percentage points higher after 2006 in states that require permission but impose no penalties, and increases by 6.8 percentage points with each $\$ 100$ of penalty per employee, a rather substantial effect. These results suggest that state wage-payment laws constituted a binding constraint on firms' pension choices to adopt auto-enroll plans. 
Table 4 shows random-effects two-limit Tobit estimates of $\theta$ in (1)-(2) from the same specifications as in Table 3, but when the dependent variable is the dollar amount of the 401(k) contribution (the lower limit is zero; the upper limit is determined by IRS contribution limits). There is little impact on 401(k) contribution amounts, indicating contribution rates under autoenrollment were similar for workers in opt-in plans. Overall, these results suggest that PPA2006 broadened, rather than deepened, retirement saving through 401(k) plans in those states with binding wage-payment laws. 


\section{References}

Madian, Brigitte C., and Dennis F. Shea, "The Power of Suggestion: Inertia in 401(k) Participation and Savings Behavior,” Quarterly Journal of Economics 116:4 (2001): 1149-87.

Nessmith, William E., Stephen P. Utkus, and Jean Young, "Measuring the Effectiveness of Automatic Enrollment," Vanguard Center for Retirement Research, Volume 31, Philadelphia, PA, 2007.

Purcell, Patrick, “Automatic Enrollment in 401(k) Plans,” Congressional Research Service Report RS21954, Washington, D.C., 2006.

U.S. Bureau of Labor Statistics, "National Compensation Survey: Employee Benefits in Private Industry in the United States, 2005” Washington, D.C., 2007.

VanDerhei, Jack, "The Impact of Automatic Enrollment in 401(k) Plans on Future Retirement Accumulations,” Employee Benefit Research Institute, Washington, D.C., 2010. 
Table 1

Sample Mean and Standard Deviation for Selected Variables

\begin{tabular}{lll} 
Variable & Mean & $\begin{array}{c}\text { Standard } \\
\text { Deviation }\end{array}$ \\
\hline Dummy if Contributes to 401(k) & 0.681 & \\
Amount of Contribution (in \$2008) & 3800 & 5,377 \\
& & \\
Earnings (in \$2008) & 64,848 & 65,416 \\
& & \\
Dummy if State Requires Written & 0.25 & \\
Permission XAfter PPA2006 & & \\
& & \\
Age & 53.9 & \\
White & 0.80 & \\
Female & 0.51 & \\
Married & 0.79 & \\
Widowed/Divorced & 0.16 & \\
Some College & 0.31 & \\
College Graduate & 0.38 & \\
Number of Children & 2.4 & \\
Union & & \\
Firm Size (in thousands) & 0.21 & \\
Other pension coverage & 20.3 & \\
\hline
\end{tabular}


Table 2

States with Wage-Payment Laws Requiring Written Permission

\begin{tabular}{|c|c|c|c|c|c|}
\hline & (1) & (2) & (3) & (4) & (5) \\
\hline State & $\begin{array}{c}\text { State } \\
\text { Employees } \\
\text { Exempt }\end{array}$ & $\begin{array}{c}\text { Local } \\
\text { Employees } \\
\text { Exempt }\end{array}$ & Other Exemptions & $\begin{array}{c}\text { Penalty } \\
\text { (\$) Per } \\
\text { Employee }\end{array}$ & $\begin{array}{l}\text { Lump-Sum } \\
\text { Penalty (\$) }\end{array}$ \\
\hline Arizona & No & No & & 0 & 0 \\
\hline California & Yes & Yes & & 100 & 0 \\
\hline Connecticut & No & No & & 5000 & 0 \\
\hline Delaware & Yes & Yes & & 5000 & 0 \\
\hline Hawaii & Yes & Yes & & 10000 & 0 \\
\hline Iowa & No & No & & 0 & 500 \\
\hline Idaho & No & No & & 0 & 500 \\
\hline Illinois & Yes & No & & 0 & 500 \\
\hline Kansas & No & No & & 0 & 0 \\
\hline Kentucky & No & No & & 0 & 0 \\
\hline Louisiana & No & No & $\begin{array}{l}\text { Less than } 10 \text { employees in Oil, } \\
\text { Manufacturing, and Mining }\end{array}$ & 0 & 500 \\
\hline Maryland & No & No & & 0 & 1000 \\
\hline Michigan & No & No & & 0 & 0 \\
\hline North Carolina & Yes & Yes & & 250 & 0 \\
\hline North Dakota & No & No & & 0 & 0 \\
\hline Nebraska & No & No & & 0 & 0 \\
\hline New Hampshire & No & No & & 0 & 200 \\
\hline New Jersey & No & No & & 0 & 1000 \\
\hline New York & No & No & & 0 & 500 \\
\hline Oregon & No & No & & 0 & 0 \\
\hline South Carolina & No & No & & 100 & 0 \\
\hline Texas & Yes & Yes & & 0 & 1000 \\
\hline Utah & Yes & Yes & Agriculture & 0 & 0 \\
\hline Virginia & No & No & & 1000 & 0 \\
\hline Vermont & No & No & & 500 & 0 \\
\hline Washington & Yes & Yes & & 0 & 1000 \\
\hline
\end{tabular}

Note: Author's tabulations from Commerce Clearing House (CCH) state wage-payment law descriptions at www.hrtools.com. 
Table 3

Random-Effect Probit Estimates of the Determinants of 401(k) Participation, Standard Errors in Parentheses, Marginal Effects in Brackets

\begin{tabular}{|c|c|c|c|c|}
\hline Explanatory Variable & $(1)$ & $(2)$ & (3) & (4) \\
\hline Dummy if State Requires Written & 0.387 & 0.375 & 0.276 & 0.166 \\
\hline \multirow[t]{2}{*}{ Permission ×After PPA2006 } & $(0.192)$ & $(0.191)$ & $(0.192)$ & $(0.196)$ \\
\hline & [0.097] & [0.094] & [0.069] & {$[0.042]$} \\
\hline Dummy if State Requires Written & & & & 0.000680 \\
\hline Permission XAfter PPA2006 X & & & & $(0.000306)$ \\
\hline \multicolumn{4}{|l|}{ Penalty } & [0.000180] \\
\hline \multirow[t]{3}{*}{ Dummy if After PPA2006 } & 0.521 & 0.382 & 0.497 & 0.492 \\
\hline & $(0.139)$ & $(0.152)$ & $(0.157)$ & $(0.157)$ \\
\hline & [0.141] & [0.104] & [0.132] & {$[0.130]$} \\
\hline \multirow[t]{3}{*}{ Earnings } & 0.182 & 0.175 & 0.136 & 0.134 \\
\hline & $(0.0280)$ & $(0.0295)$ & $(0.0478)$ & $(0.0480)$ \\
\hline & {$[0.050]$} & {$[0.048]$} & {$[0.036]$} & {$[0.035]$} \\
\hline \multirow[t]{3}{*}{ Earnings Squared } & -0.00131 & -0.00127 & -0.000474 & -0.000298 \\
\hline & $(0.000745)$ & $(0.000727)$ & $(0.00236)$ & $(0.00238)$ \\
\hline & {$[-0.000358]$} & {$[-0.000349]$} & {$[-0.00013]$} & {$[-0.00008]$} \\
\hline \multirow[t]{3}{*}{ Dummy if other pension coverage } & -1.151 & -1.147 & -1.168 & -1.163 \\
\hline & $(0.146)$ & $(0.145)$ & $(0.149)$ & $(0.148)$ \\
\hline & {$[-0.293]$} & {$[-0.23]$} & {$[-0.290]$} & {$[-0.288]$} \\
\hline \multirow[t]{3}{*}{ Age } & & 0.0431 & 0.0244 & 0.0247 \\
\hline & & $(0.0191)$ & $(0.0187)$ & $(0.0187)$ \\
\hline & & {$[0.012]$} & {$[0.006]$} & {$[0.007]$} \\
\hline \multirow[t]{3}{*}{ White } & & 0.116 & 0.0341 & 0.0288 \\
\hline & & $(0.166)$ & $(0.162)$ & $(0.161)$ \\
\hline & & {$[0.033]$} & [0.009] & {$[0.008]$} \\
\hline \multirow[t]{3}{*}{ Female } & & 0.248 & 0.153 & 0.143 \\
\hline & & $(0.138)$ & $(0.150)$ & $(0.150)$ \\
\hline & & {$[0.068]$} & {$[0.041]$} & {$[0.038]$} \\
\hline \multirow[t]{3}{*}{ Married } & & 0.337 & 0.320 & 0.325 \\
\hline & & $(0.295)$ & $(0.286)$ & $(0.285)$ \\
\hline & & {$[0.100]$} & {$[0.092]$} & {$[0.093]$} \\
\hline \multirow[t]{3}{*}{ Widowed or Divorced } & & -0.228 & -0.145 & -0.135 \\
\hline & & $(0.314)$ & $(0.307)$ & $(0.306)$ \\
\hline & & {$[-0.067]$} & {$[-0.041]$} & {$[-0.037]$} \\
\hline \multirow[t]{3}{*}{ Some College } & & 0.0205 & -0.0237 & -0.0238 \\
\hline & & $(0.158)$ & $(0.158)$ & $(0.158)$ \\
\hline & & {$[0.006]$} & {$[-0.006]$} & {$[-0.006]$} \\
\hline College Graduate & & 0.0572 & 0.0230 & 0.0137 \\
\hline
\end{tabular}




\begin{tabular}{lcccc}
\hline & & $(0.167)$ & $(0.183)$ & $(0.183)$ \\
& & {$[0.016]$} & {$[0.006]$} & {$[0.004]$} \\
Number of Children & & -0.0699 & -0.0825 & -0.0847 \\
& & $(0.0388)$ & $(0.0379)$ & $(0.0379)$ \\
State Effects & & {$[-0.019]$} & {$[-0.022]$} & {$[-0.022]$} \\
Employment Characteristics & Yes & Yes & Yes & Yes \\
\hline
\end{tabular}


Table 4

Two-Limit Random-Effect Tobit Estimates of the Determinants of 401(k) Contribution Amounts, Standard Errors in Parentheses

\begin{tabular}{lcccc}
\hline Explanatory Variable & $(1)$ & $(2)$ & $(3)$ & $(4)$ \\
\hline Dummy if State Requires Written & 363.2 & 391.5 & 119.8 & 21.28 \\
Permission XAfter PPA2006 & $(508.3)$ & $(507.2)$ & $(506.4)$ & $(517.3)$ \\
& & & 0.584 \\
Dummy if State Requires Written & & & $(0.623)$ \\
Permission XAfter PPA2006x & & & \\
Penalty & & & Yes \\
per Employee & & & Yes \\
State Effects & Yes & Yes & Yes \\
Quadratic in Earnings & Yes & Yes & Yes & Yes \\
Other Pension Coverage & Yes & Yes & Yes & Yes \\
Demographic Characteristics & No & No & Yes & Yes \\
Employment Characteristics & No & No & & \\
\hline
\end{tabular}




\section{RECENT WORKING PAPERS FROM THE \\ CENTER FOR RETIREMENT RESEARCH AT BOSTON COLLEGE}

Asset Cycles and the Retirement Decisions of Older Workers

Jan Ondrich, October 2010

Price Deflators, the Trust Fund Forecast, and Social Security Solvency

Barry Bosworth, October 2010

The Impact of a DROP Program on the Age of Retirement and Employer Pension Costs Samson Alva, Norma B. Coe, and Anthony Webb, September 2010

Housing Consumption in Late Life: The Role of Income, Health Shocks, and Marital Shocks

Douglas A. Wolf and Janet M. Wilmoth, September 2010

Adjusting Social Security for Increasing Life Expectancy: Effects on Progressivity

Courtney Monk, John A. Turner, and Natalia A. Zhivan, August 2010

Work and Retirement Patterns for the G.I. Generation, Silent Generation, and Early Boomers: Thirty Years of Change

Richard W. Johnson, Barbara A. Butrica, and Corina Mommaerts, July 2010

Spousal Health Shocks and the Timing of the Retirement Decision in the Face of ForwardLooking Financial Incentives

Courtney Harold Van Houtven and Norma B. Coe, June 2010

Incorporating Employee Heterogenity Into Default Rules for Retirement Plan Selection Gopi Shah Godi and Colleen Flaherty Manchester, May 2010

Accurately Measuring Health Over the Life Course

Fabian Lange and Doug McKee, May 2010

Getting to the Top of Mind: How Reminders Increase Saving

Dean Karlan, Margaret McConnell, Sendhil Mullainathan, and Jonathan Zinman, April 2010

The Shrinking Tax Preference for Pension Savings: An Analysis of Income Tax Changes, 1985-2007

Gary Burtless and Eric Toder, March 2010

Social Security, Benefit Claiming and Labor Force Participation: A Quantitative General Equilibrium Approach

Selahattin Imrohoroğlu and Sagiri Kitao, March 2010

How Much Is Enough? The Distribution of Lifetime Health Care Costs

Anthony Webb and Natalia Zhivan, February 2010 